\title{
Management of sulphur fertiliser to improve durum wheat production and minimise S leaching
}

\author{
Laura Ercoli $^{\mathrm{a}, *}$, Iduna Arduini $^{\mathrm{b}}$, Marco Mariotti ${ }^{\mathrm{b}}$, Leonardo Lulli ${ }^{\mathrm{b}}$, Alessandro Masoni ${ }^{\mathrm{b}}$ \\ a Scuola Superiore Sant'Anna, p.zza Martiri della Libertà 33, 56127 Pisa, Italy \\ ${ }^{\mathrm{b}}$ Dipartimento di Agronomia e Gestione dell'Agroecosistema, via S. Michele degli Scalzi 2, 56124 Pisa, Italy
}

\section{A R T I C L E I N F O}

\section{Article history:}

Received 4 October 2011

Received in revised form

24 November 2011

Accepted 19 December 2011

\section{Keywords:}

Triticum durum

Sulphur fertilisation

Sulphur leaching

Sulphur balance

\begin{abstract}
A B S T R A C T
Optimisation of S release from decomposing soil organic matter and S fertiliser related to plant S uptake is a central issue and goal in applied research in agricultural systems. Two lysimeter experiments were conducted in central Italy in two subsequent seasons on two commercial durum wheat cultivars to investigate the effects on yield, $\mathrm{S}$ and $\mathrm{N}$ uptake and leaching of different rates of $\mathrm{N}$ and $\mathrm{S}$ fertilisers, soil type and split applications of S. Sulphur fertiliser increased grain yield and N and S uptake of both varieties. Grain yield increase was mainly due to an increase of the number of kernels per spike, which was interpreted as a stimulation of the initiation of spikelets and/or florets, or to a reduction the floret mortality. As an average of the two seasons, S leaching during wheat cycle was $35 \mathrm{~kg} \mathrm{Sha}^{-1}$. Sulphur fertiliser rate increased $S$ concentration in drainage water and consequently $S$ leached during wheat cycle. Compared to unfertilised control, S leached was by $13 \mathrm{~kg} \mathrm{ha}^{-1}$ higher at $60 \mathrm{~kg} \mathrm{Sha}^{-1}$ and by $19 \mathrm{~kg} \mathrm{ha}^{-1}$ higher at $120 \mathrm{kgSha}^{-1}$. The splitting of sulphur fertiliser during crop cycle modified both grain yield and $S$ leaching. The highest grain yield and $S$ plant uptake was obtained with the splitting of $S$ rate into $60 \mathrm{~kg} \mathrm{Sha}^{-1}$ before seeding and $60 \mathrm{~kg} \mathrm{Sha}^{-1}$ at stem elongation and the lowest amount of $S$ lost by leaching occurred with the application of $36 \mathrm{~kg} \mathrm{Sha}^{-1}$ before seeding and $84 \mathrm{~kg} \mathrm{~S} \mathrm{ha}^{-1}$ at stem elongation. Sulphur output was equally accounted for by leaching and plant uptake. The input-output balance of $S$ was positive in both experiments only when the higher $\mathrm{S}$ rate was applied, as more $\mathrm{S}$ was imported than removed. Thus, no substantial $S$ deficit may be expected in short term, provided that high $S$ fertiliser rate is applied and the availability of $\mathrm{S}$ is synchronised with plant needs.
\end{abstract}

(c) 2011 Elsevier B.V. All rights reserved.

\section{Introduction}

Sulphur is an essential nutrient for plants since it is involved in key steps of plant metabolism. During the last decades, sulphur deficiency in agricultural soils has become widespread in many European countries. This is mainly caused by the reductions in $\mathrm{SO}_{2}$ emissions, the use of low S-containing fertilisers, the low $\mathrm{S}$ return with farmyard manure, and the declining use of S-containing fungicides (Schnug, 1991; de Ruiter and Martin, 2001; Scherer, 2001).

For durum wheat, it is well established that S deficiency can adversely affect plant growth and grain quality through its effect on protein composition (Lerner et al., 2006; Ercoli et al., 2011). The response of wheat to sulphur fertiliser was found to vary considerably between sites and years, due to differences in soil or climatic conditions (Pedersen et al., 1998). Especially variations in soil organic matter composition as well as winter rainfall and spring

\footnotetext{
* Corresponding author. Tel.: +39 050883357; fax: +39 050883215 .

E-mail address: ercoli@sssup.it (L. Ercoli).
}

temperature may give differences in the level of sulphate available at the time of plant demand (Eriksen and Askegaard, 2000).

Sulphur is present in soil in inorganic and organic forms, the former being generally much less abundant in most agricultural soils, accounting for less than 10\% of the total S (Bohn et al., 1986). Sulphate is the most common form of inorganic $S$ in soil and can be present as $\mathrm{SO}_{4}{ }^{2-}$ either dissolved in soil solution or adsorbed to soil particles and insoluble sulphur (Barber, 1995). Soil organic S exists as C-bonded S or as sulphate esters (Eriksen, 2009). The sulphur stock in soil is subject to biotic processes, causing continuous degradation and re-polymerisation, and to abiotic processes, as precipitation phenomena, atmospheric dry deposition or leaching of water-soluble S compounds. Mineralisation and immobilisation of $S$ occur concurrently, and the release or incorporation of inorganic sulphate into soil organic matter is thus a net result of several processes (Maynard et al., 1983; Ghani et al., 1993). Sulphur may be retained in soil via two major mechanisms: absorption on the soil solid phase or incorporation into organic forms. The retention of sulphate in soils by absorption depends on the nature of the colloidal system, $\mathrm{pH}$, sulphate concentration and the concentration of other ions in the solution (Harward and Reisenauer, 1966). Even for 
soils with a marked capacity to retain sulphate, the strength of the retention is weak, as adsorbed sulphate can be removed by repeated extraction with water (Chao et al., 1962). Thus the fate of S released from microbial degradation of organic matter or from fertiliser is either to be leached when the water moves vertical downward in the soil profile or absorbed by the plant.

Leaching is potentially one of the most important contributors to $\mathrm{S}$ depletion. Sulphur is leached both as sulphate and as dissolved organic sulphur (DOS), but the latter is much less abundant in leachate than the former (Arowolo et al., 1994; Zhao and McGrath, 1994). Over a three-year period, Riley et al. (2002) estimated that DOS accounted for $6 \pm 10 \%$ of the total $S$ lost to drainage. Estimates of sulphate leaching by lysimeters and river catchments generally ranges from 1 to $60 \mathrm{~kg} \mathrm{Sha}^{-1} \mathrm{y}^{-1}$ (Eriksen et al., 1998; Eriksen, 2009), but also higher figures of $100 \mathrm{~kg} \mathrm{Sha}^{-1} \mathrm{y}^{-1}$ have been reported (Guzys and Aksomaitiene, 2005).

Agricultural management can cause considerable variations in sulphate leaching. To minimise the risks of large $\mathrm{S}$ leaching losses from wheat crop the pattern of S distribution needs to be optimised in relation to crop S demand (Korentajer et al., 1984; Eriksen and Askegaard, 2000; Riley et al., 2002). This is accomplished by making $S$ available just prior to or synchronised with crop $S$ uptake, while $S$ mineralisation during time periods of low or no crop uptake should be minimised (Eriksen et al., 2002). Optimisation of S release from decomposing soil organic matter and S fertiliser related to plant $S$ uptake is a central issue and goal in applied research concerning $S$ in agricultural systems, and also in this paper. The present work was therefore undertaken to determine $\mathrm{S}$ and $\mathrm{N}$ leaching and $\mathrm{S}$ fertiliser response from durum wheat crop. The effects of different rates of $\mathrm{N}$ and $\mathrm{S}$ fertilisers, soil types and split applications of S were investigated. Sulphur input and output balances were determined in order to evaluate the long-term possibility of an adequate $S$ supply for the wheat crop.

\section{Material and methods}

Two experiments were conducted with durum wheat (Triticum durum Desf.) in two successive growing seasons, 2003-2004 and 2004-2005, at the experimental station of the Department of Agronomy and Agroecosystem Management of the University of Pisa, Italy, that is located at a distance of approximately $10 \mathrm{~km}$ from the sea $\left(43^{\circ} 40^{\prime} \mathrm{N}, 10^{\circ} 19^{\prime} \mathrm{E}\right)$ and $1 \mathrm{~m}$ above sea level. The climate of the experimental site is cold, humid Mediterranean with mean annual maximum and minimum daily air temperatures of 20.2 and $9.5^{\circ} \mathrm{C}$, respectively, and precipitation of $971 \mathrm{~mm}$, with $688 \mathrm{~mm}$ received during the period of durum wheat cultivation, that is from November through July (Moonen et al., 2001).

Both experiments were conducted with three replications in randomised complete block designs utilising an open-air lysimeter installation. This consisted of thirty-six lysimeters of $100-\mathrm{L}$ volume $\left(0.25-\mathrm{m}^{2}\right.$ area and $0.4-\mathrm{m}$ height), arranged in two rows of 18 , spaced $15 \mathrm{~cm}$ and embedded in expanded clay to smooth daily fluctuations in soil temperature. Lysimeters were filled with a soil tamped to about original soil bulk density, and were attached to a 5-cm rigid PVC drain that ended in a central collection facility. Soil samples (0-40 cm depth) were collected in December 2003 and December 2004 before wheat seeding for the determination of soil properties (Table 1). Samples were air dried, grounded, and analysed for texture (hydrometer method), $\mathrm{pH}$ (saturated paste method), organic matter (Walkley and Black method), total N (Kjeldahl method), available P (Olsen method), available K (ammonium acetate extraction) and total $\mathrm{S}$ (dry combustion and infrared detection, Schumacher et al., 1995). The fertiliser S and N treatments, as well as the $P$ and $K$ rates were calculated based on the balance approach, which is considered a more reliable method than traditional soil tests to determine plant nutrient availability (Zhao et al., 1999).

Phosphorus and potassium were applied preplanting as triple mineral phosphate and potassium chloride at a rate of $100 \mathrm{~kg} \mathrm{ha}^{-1}$ $\mathrm{P}_{2} \mathrm{O}_{5}$ and $\mathrm{K}_{2} \mathrm{O}$. The additions of nitrogen and sulphur fertilisers are described later for each experiment.

Two durum wheat varieties, Creso and Svevo, were sown at a rate of 100 viable seeds per container, corresponding to 400 viable seeds per $\mathrm{m}^{2}$, in rows spaced $15 \mathrm{~cm}$ apart on 12 December 2003 and 15 December 2005. Creso is an old variety (released in 1974) that was widely cultivated in Central Italy in the past 20 years and is still in use. It is characterised by a moderate but constant yield, medium grain quality and a high adaptability to different environmental conditions. Svevo is a more recent variety characterised by taller size, higher productivity and improved grain quality.

Crops were irrigated when necessary to avoid water stress that may occur in plants grown in containers, especially during grain filling. In both years, no irrigation was applied before anthesis and two irrigations were applied between anthesis and maturity, utilising a microirrigation system until field capacity was reached. Weed control was performed throughout wheat cycle by hand hoeing.

Leachates from each lysimeter were collected during the entire research period in both years after each major rainfall event in a 20-L PVC tank. Leachate volumes were measured and their $\mathrm{N}-\mathrm{NO}_{3}$ and $\mathrm{S}-\mathrm{SO}_{4}$ concentrations were determined with a Dionex ion cromatograph model DX-120. The flow-weighted $\mathrm{N}-\mathrm{NO}_{3}$ and $\mathrm{S}-\mathrm{SO}_{4}$ concentrations for the whole leaching period were calculated by summing up $\mathrm{N}-\mathrm{NO}_{3}$ and $\mathrm{S}-\mathrm{SO}_{4}$ mass collected in the period divided by the total leachate volume collected in the period. $\mathrm{N}-\mathrm{NO}_{3}$ and $\mathrm{S}-\mathrm{SO}_{4}$ concentrations were determined also in rainfall and irrigation water. Mean $\mathrm{N}-\mathrm{NO}_{3}$ concentration was $2.4 \mathrm{mg} \mathrm{L}^{-1}$ in rainfall and $1.9 \mathrm{mg} \mathrm{L}^{-1}$ in irrigation water. Mean $\mathrm{S}-\mathrm{SO}_{4}$ concentration was $7.4 \mathrm{mg} \mathrm{L}^{-1}$ in rainfall and $2.6 \mathrm{mg} \mathrm{L}^{-1}$ in irrigation water.

At physiological maturity (stage 90 of the scale of Zadoks et al. (1974)), plants from each container were manually cut at ground level and were partitioned into culms, leaves, chaff and grain. Roots were separated from the soil by gently washing with water until they were totally clean. For dry weight determination, samples from all plant parts were oven dried at $65^{\circ} \mathrm{C}$ to constant weight. Mean kernel dry weight was also measured and number of kernels per unit area and harvest index (HI) were calculated. Samples of each plant part were analysed for nitrogen (Kjeldahl method) and sulphur (wet ashing and infrared detection method) concentrations; $\mathrm{N}$ and $\mathrm{S}$ contents were calculated by multiplying $\mathrm{N}$ or $\mathrm{S}$ concentration by dry weight.

\subsection{Experiment 1 - nitrogen and sulphur rates}

The research was carried out in the 2003-2004 wheat growing season. The varieties Creso and Svevo were grown with two levels of $\mathrm{N}$ application, low (120 kg Nha${ }^{-1}$ ) and high (180 kg Nha-1), hereafter referred to as N120 and N180, respectively, and three levels of $\mathrm{S}$ application, nil, high $\left(60 \mathrm{~kg} \mathrm{Sha}^{-1}\right)$ and very high $\left(120 \mathrm{~kg} \mathrm{Sha}^{-1}\right)$, hereafter referred to as S0, S60 and S120, respectively. Nitrogen was applied as urea. The rate of $120 \mathrm{~kg} \mathrm{~N} \mathrm{ha}^{-1}$ was splitted into two applications of $60 \mathrm{~kg} \mathrm{Nha}^{-1}$, before seeding and at first node detectable (stage 31 - 4 April 2004), that of $180 \mathrm{~kg} \mathrm{~N} \mathrm{ha}^{-1}$ was splitted into three applications of $60 \mathrm{~kg} \mathrm{~N} \mathrm{ha}^{-1}$ before seeding, at first node detectable and 15 days after this stage (26 May 2004). Sulphur was applied preplanting as agricultural gypsum $\left(\mathrm{CaSO}_{4} \cdot 2 \mathrm{H}_{2} \mathrm{O}\right)$. The soil type was loam according to the USDA classification.

\subsection{Experiment 2 - soil type and splitting of sulphur fertilisation}

The research was carried out in the 2004-2005 wheat growing season. The varieties Creso and Svevo were grown on two soil types 
Table 1

Soil properties in Experiments 1 and 2.

\begin{tabular}{|c|c|c|c|c|}
\hline \multirow[t]{2}{*}{ Parameter } & \multirow[t]{2}{*}{ Unit } & \multirow[t]{2}{*}{ Experiment 1} & \multicolumn{2}{|l|}{ Experiment 2} \\
\hline & & & Clay-loam soil & Sandy-loam soil \\
\hline Sand $(2 \mathrm{~mm}>\emptyset>0.05 \mathrm{~mm})$ & $\%$ & 48.6 & 38.9 & 64.9 \\
\hline Silt $(0.05 \mathrm{~mm}>\emptyset>0.002 \mathrm{~mm})$ & $\%$ & 33.6 & 28.7 & 24.0 \\
\hline $\operatorname{Clay}(\varnothing<0.002 \mathrm{~mm})$ & $\%$ & 17.8 & 32.4 & 11.1 \\
\hline $\mathrm{pH}$ & & 8.3 & 7.2 & 6.8 \\
\hline Organic matter & $\%$ & 1.8 & 1.7 & 1.3 \\
\hline Total N & $\mathrm{g} \mathrm{kg}^{-1}$ & 0.9 & 1.1 & 0.8 \\
\hline Available P & $\mathrm{mg} \mathrm{kg}^{-1}$ & 5.4 & 5.2 & 0.8 \\
\hline Available K & $\mathrm{mg} \mathrm{kg}^{-1}$ & 68.7 & 80.2 & 16.5 \\
\hline Total S & $\mathrm{g} \mathrm{kg}^{-1}$ & 0.32 & 0.34 & 0.23 \\
\hline
\end{tabular}

(sandy-loam and clay-loam, according to the USDA classification) with three splittings of $S$ fertilisation: (i) completely before seeding, (ii) splitted $60 \mathrm{~kg} \mathrm{~S} \mathrm{ha}^{-1}$ preplanting and (iii) $60 \mathrm{~kg} \mathrm{Sha}^{-1}$ at first node detectable (2 April 2005) and splitted $34 \mathrm{~kg} \mathrm{Sha}^{-1}$ preplanting and $86 \mathrm{~kg} \mathrm{Sha}^{-1}$ at first node detectable, hereafter referred to as S120-0, S60-60 and S36-84, respectively. Sulphur was applied as agricultural gypsum $\left(\mathrm{CaSO}_{4} \cdot 2 \mathrm{H}_{2} \mathrm{O}\right)$ at the total rate of $120 \mathrm{~kg} \mathrm{Sha}^{-1}$ for all treatments. Nitrogen was applied at the rate of $180 \mathrm{~kg} \mathrm{~N} \mathrm{ha}^{-1}$ and was splitted $60 \mathrm{~kg} \mathrm{ha}^{-1}$ preplanting as ammonium nitrate, $60 \mathrm{~kg} \mathrm{ha}^{-1}$ at first node detectable and $60 \mathrm{~kg} \mathrm{ha}^{-1} 15$ days after this stage as urea.

\subsection{Data analysis}

Statistical analysis of data was performed separately for the two experiments. Data were treated by ANOVA; in the first experiment the main effects of variety, $\mathrm{N}$ rate, $\mathrm{S}$ rate and their interactions were tested, in the second the main effects of variety, soil type, splitting of S fertiliser, and their interactions were tested. Significantly different means were separated at the 0.05 probability level by the least significant difference test (Steel et al., 1997).

\section{Results}

\subsection{Experiment 1 - nitrogen and sulphur rates}

\subsubsection{Grain yield and yield components}

Grain yield and its components were not affected by the interactions among varieties, $\mathrm{N}$ rates and $\mathrm{S}$ rates. Grain yield of Svevo was, on average, by $17 \%$ higher than that of Creso (Table 2). The increase was attributed to higher number of spikes per unit area $(+21 \%)$, owing to a greater tillering rate, and number of kernels per spike ( $+30 \%)$. Conversely, mean kernel weight of Svevo was by $8 \%$ lower. Dry weight of all plant parts except grain was higher in Creso than in Svevo and, consequently, harvest index was lower in Creso (results not shown).
The increase of $\mathrm{N}$ rate from 120 to $180 \mathrm{~kg} \mathrm{~N} \mathrm{ha}^{-1}$ increased grain yield by $9 \%$, owing to an increase of the number of spikes per unit area (13\%). Moreover, the increase of $\mathrm{N}$ rate slightly reduced mean kernel weight and did not affect the number of kernels per spike (Table 2). The increase of $\mathrm{N}$ rate also increased plant dry weight by $12 \%$, due to the increase of all plant parts.

The increase of $S$ rate from 0 to 60 and $120 \mathrm{~kg} \mathrm{Sha}^{-1}$ progressively increased grain yield (by $5.4 \%$ from S0 to S120), and dry weight of culms (6.6\%) and of roots (12.5\%) (Table 2). Higher grain yield was solely due to the increase of the number of kernels per spike.

\subsubsection{Sulphur concentration and content}

Sulphur concentration in all plant parts was higher at the highest $\mathrm{N}$ and $\mathrm{S}$ fertiliser rates, but the effect was statistically significant only in grain and roots. Sulphur concentration in grain increased from 1.2 of the control to $1.5 \mathrm{~g} \mathrm{~kg}^{-1}$ of the highest $\mathrm{N}$ and $\mathrm{S}$ fertiliser rates. The interaction between $\mathrm{N}$ rate and $\mathrm{S}$ rate was significant only for $\mathrm{S}$ content of roots. At the lower $\mathrm{N}$ fertiliser rate, the highest level of $S$ increased by $7 \% S$ content in roots compared to unfertilised control, while at the higher $\mathrm{N}$ rate the increase due to $\mathrm{S}$ fertiliser was by $25 \%$ (Fig. 1). Averaged over fertilisers rates, Creso gave higher $\mathrm{S}$ content in grain and lower in leaves and culms, compared to Svevo (Table 3).

The increase of $\mathrm{N}$ fertiliser increased $\mathrm{S}$ content of all plant parts, the rate of increase ranged from $18 \%$ in roots to $40 \%$ in leaves (Table 3 ). Conversely, the increase of $S$ fertiliser progressively increased only the $\mathrm{S}$ content of grain and culms, respectively by 28 and $23 \%$. All summarised, the uptake of S by the whole plant was by $9.1 \mathrm{~kg} \mathrm{ha}^{-1}$ greater at N180 than at N120 and by $7.1 \mathrm{~kg} \mathrm{ha}^{-1}$ greater at S120, compared to S0.

\subsubsection{Nitrogen concentration and content}

Treatments did not affect significantly $\mathrm{N}$ concentration that was, on average, $20.1,7.6,3.1,7.1$ and $8.8 \mathrm{~g} \mathrm{~kg}^{-1}$ respectively in grain, leaves, culms, chaff and roots. Conversely, nitrogen content of all

Table 2

Experiment 1 - dry weight of grain, leaves, culms, chaff, roots and yield components. Variety, nitrogen rate and sulphur rate mean effects.

\begin{tabular}{|c|c|c|c|c|c|c|c|c|}
\hline Treatments & Grain & Leaves & Culms & Chaff & Roots & Spike number & Kernel number & Mean kernel wt. \\
\hline & & & $\left(\mathrm{tha}^{-1}\right)$ & & & $\left(\mathrm{nm}^{-2}\right)$ & $\left(\right.$ n spike $\left.^{-1}\right)$ & $(\mathrm{mg})$ \\
\hline \multicolumn{9}{|l|}{ Variety } \\
\hline Svevo & $5.5 \mathrm{a}$ & $1.0 \mathrm{a}$ & $5.5 \mathrm{a}$ & $1.7 \mathrm{a}$ & $1.6 \mathrm{a}$ & $470.3 \mathrm{a}$ & $25.3 \mathrm{a}$ & $46.3 \mathrm{a}$ \\
\hline Creso & $4.7 \mathrm{~b}$ & $1.2 \mathrm{~b}$ & $6.3 \mathrm{~b}$ & $1.8 \mathrm{~b}$ & $1.9 \mathrm{~b}$ & 389.7 b & $23.5 \mathrm{~b}$ & $51.4 \mathrm{~b}$ \\
\hline \multicolumn{9}{|l|}{ Nitrogen rate } \\
\hline N120 & $4.9 \mathrm{a}$ & $1.0 \mathrm{a}$ & $5.6 \mathrm{a}$ & 1.7 & $1.6 \mathrm{a}$ & $404.3 \mathrm{a}$ & $24.5 \mathrm{a}$ & $49.3 \mathrm{a}$ \\
\hline N180 & $5.3 \mathrm{~b}$ & $1.2 \mathrm{~b}$ & $6.2 \mathrm{~b}$ & 1.9 & $1.9 \mathrm{~b}$ & $455.7 \mathrm{~b}$ & $24.3 \mathrm{a}$ & $48.4 \mathrm{~b}$ \\
\hline \multicolumn{9}{|l|}{ Sulphur rate } \\
\hline SO & $4.9 \mathrm{a}$ & $1.1 \mathrm{a}$ & $5.7 \mathrm{a}$ & $1.8 \mathrm{a}$ & $1.6 \mathrm{a}$ & $432.0 \mathrm{a}$ & $23.8 \mathrm{a}$ & $48.4 \mathrm{a}$ \\
\hline S60 & $5.1 \mathrm{ab}$ & $1.1 \mathrm{a}$ & $6.0 \mathrm{ab}$ & $1.8 \mathrm{a}$ & $1.7 \mathrm{ab}$ & $431.5 \mathrm{a}$ & $24.4 \mathrm{ab}$ & $49.1 \mathrm{a}$ \\
\hline S120 & $5.2 \mathrm{~b}$ & $1.1 \mathrm{a}$ & $6.1 \mathrm{~b}$ & $1.8 \mathrm{a}$ & $1.9 \mathrm{~b}$ & $426.5 \mathrm{a}$ & $25.0 \mathrm{~b}$ & $49.1 \mathrm{a}$ \\
\hline
\end{tabular}

Within treatments variety, $\mathrm{N}$ rate and $\mathrm{S}$ rate, numbers followed by the same letter are not significantly different at $P<0.05$. 

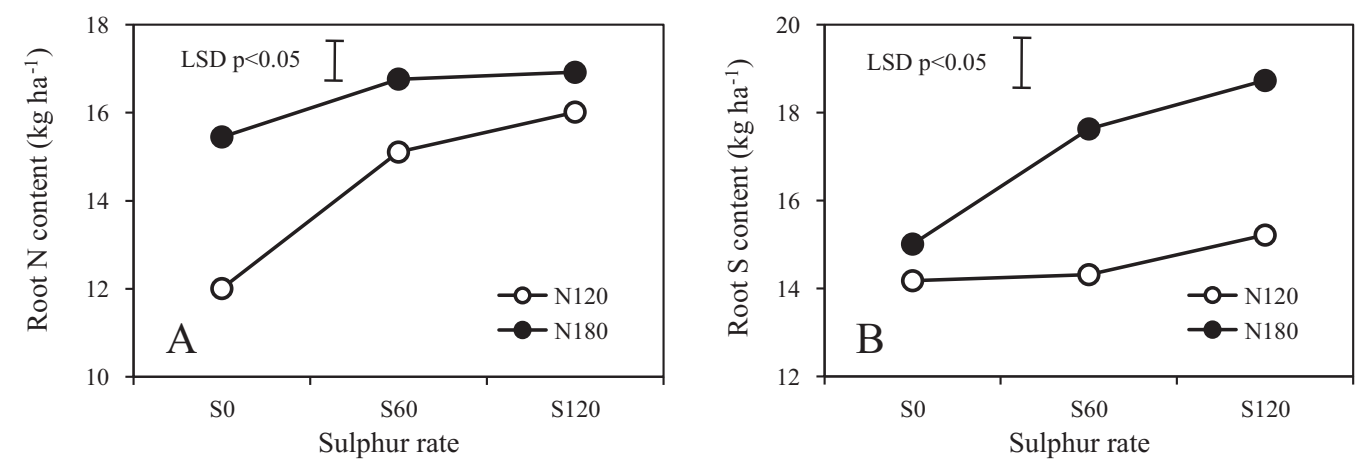

Fig. 1. Experiment 1 - nitrogen (A) and sulphur (B) content of roots as affected by nitrogen rate x sulphur rate interaction.

Table 3

Experiment 1 - sulphur content of grain, leaves and culms. Variety, nitrogen rate and sulphur rate mean effects.

\begin{tabular}{llll}
\hline Treatments & Grain & Leaves & Culms \\
\hline & & $\left(\mathrm{kg} \mathrm{ha}^{-1}\right)$ & \\
\cline { 2 - 3 } & & & \\
Variety & $8.1 \mathrm{a}$ & $1.5 \mathrm{a}$ & $13.2 \mathrm{a}$ \\
$\quad$ Svevo & $5.8 \mathrm{~b}$ & $2.0 \mathrm{~b}$ & $14.9 \mathrm{~b}$ \\
$\quad$ Creso & & $1.4 \mathrm{a}$ & $12.1 \mathrm{a}$ \\
Nitrogen rate & $6.0 \mathrm{a}$ & $2.0 \mathrm{~b}$ & $15.9 \mathrm{~b}$ \\
N120 & $8.0 \mathrm{~b}$ & & \\
N180 & & $1.6 \mathrm{a}$ & $12.6 \mathrm{a}$ \\
Sulphur rate & $6.1 \mathrm{a}$ & $1.8 \mathrm{a}$ & $14.0 \mathrm{ab}$ \\
S0 & $7.0 \mathrm{ab}$ & $1.8 \mathrm{a}$ & $15.4 \mathrm{~b}$ \\
S60 & $7.8 \mathrm{~b}$ &
\end{tabular}

Within treatments variety, $\mathrm{N}$ rate and $\mathrm{S}$ rate, numbers followed by the same letter are not significantly different at $P<0.05$.

plant parts except chaff varied between varieties and was affected by $\mathrm{N}$ and $\mathrm{S}$ rates. Grain N content of Svevo was by $28 \%$ higher than that of Creso, which had instead higher N content in leaves $(+15 \%)$, culms $(+15 \%)$ and roots $(+25 \%)$ (results not shown). As a consequence, $\mathrm{N}$ harvest index was by $11 \%$ higher in Svevo compared to Creso. The uptake of $\mathrm{N}$ with the higher $\mathrm{N}$ rate was $186 \mathrm{~kg} \mathrm{ha}^{-1}$ in Svevo and $166 \mathrm{~kg} \mathrm{ha}^{-1}$ in Creso.

At the lower $\mathrm{N}$ fertiliser rate, the highest level of S increased by $33 \% \mathrm{~N}$ content in roots compared to unfertilised control, while at the higher $\mathrm{N}$ rate the increase due to $\mathrm{S}$ fertiliser was by $10 \%$ (Fig. 1). Both $\mathrm{N}$ and $\mathrm{S}$ fertilisers increased nitrogen content in grain, leaves and culms. As a consequence, the uptake of $\mathrm{N}$ of the whole plant was by $39 \mathrm{~kg} \mathrm{ha}^{-1}$ greater at N180 and $18 \mathrm{~kg} \mathrm{ha}^{-1}$ greater at S120, compared to the lower fertiliser rates (results not shown).

\subsubsection{Sulphur leaching}

No significant differences were observed in drainage water among any of the treatments tested. Drainage water was roughly correlated to rainfall, being higher in January, February and April when the highest rainfalls occurred. Rainfall during 2003-2004 wheat growing season was close to normal values for the site. Sulphur concentration in drainage water and leached $S$ were affected only by $S$ fertilisation. In the period from January to April, S concentration was higher than $16 \mathrm{mg} \mathrm{L}^{-1}$ and increased with the increase of $S$ rate (Fig. 2). The highest $S$ concentrations from the $S$ fertilised treatments occurred in March, while from unfertilised treatment it occurred earlier, in February. In March, a 2-fold higher S concentration was recorded in leachates from $\mathrm{S}$ fertilised soils compared to unfertilised one.

The quantity of S lost to the drainage water from S fertilised and control treatments was highest in January and February. Sulphur leached up to April increased with the increase of S rate, while in May values were low and unaffected by $S$ fertiliser. Over the wheat cycle, S leached from S60 and S120 was by 13 and $19 \mathrm{~kg} \mathrm{ha}^{-1}$ higher respectively than from the unfertilised crop (Fig. 2).

\subsubsection{Nitrogen leaching}

No significant differences were observed in $\mathrm{N}$ concentration in drainage and $\mathrm{N}$ leaching between any of the treatments tested. Nitrogen concentration in water was higher following seeding, in January and February, and decreased thereafter to minimal values in May (Fig. 2). Averaged over all treatments, total amount of $\mathrm{N}$ lost during wheat cycle was $26 \mathrm{~kg} \mathrm{ha}^{-1}$, almost entirely accounted for by $\mathrm{N}$ leaching in January and February (39\% and $43 \%$ respectively of the total leached N). Following March, leaching losses were negligible.

\subsubsection{Sulphur balance}

Averaged over varieties, S output from soil (leaching plus plant uptake) was similar for all treatments and increased with the increase of S fertiliser rate. Sulphur balance, calculated as the difference between estimated inputs (S fertiliser and wet deposition) and outputs, was seriously negative from unfertilised crop, only slightly negative from S60 and positive from S120 (Table 4). Differences between treatments were due to the increase of plant $S$ uptake due to higher $S$ fertiliser. To have balanced inputs and outputs, a $\mathrm{S}$ fertiliser rate lower than $120 \mathrm{~kg} \mathrm{Sha}^{-1}$ but higher than $60 \mathrm{~kg} \mathrm{Sha}^{-1}$ should be applied.

\subsection{Experiment 2 - soil type and splitting of sulphur fertilisation}

\subsubsection{Yield and yield components}

Grain yield and its components were not affected by the interactions among varieties, $\mathrm{N}$ rates and $\mathrm{S}$ rates. Grain yield of Svevo was on average by $12 \%$ higher than that of Creso, owing to a higher mean kernel weight (Table 5). Conversely, dry weight of leaves and culms were, respectively, $13 \%$ and $15 \%$ higher in Creso than Svevo. Finally, harvest index was $14 \%$ lower in Creso (results not shown).

Soil type greatly affected crop production. Grain yield of plants grown in clay loam soil was $43 \%$ higher, and dry weight of leaves and culms were respectively 43 and $44 \%$ higher compared to plants grown in sandy loam soil (Table 5). Root dry weight was unchanged between the two soil types. The increase of grain yield between clay loam and sandy loam soil was due to higher number of spikes per unit area $(+6 \%)$, number of kernels per spike $(+10 \%)$ and mean kernel weight $(+20 \%)$. The differences of mean kernel weight are not caused by variations of water availability, as crops were irrigated during grain filling.

Conversely, S splitting had scarce effect on dry weight of all plant parts: the treatment S60-60 increased slightly grain and roots dry weight (Table 5). The higher grain yield was due to the increase of the number of spikes per unit area. The treatments S120-0 or S60-60 gave similar grain yield, but the former had higher number of kernels per spike and the latter higher mean kernel weight. 

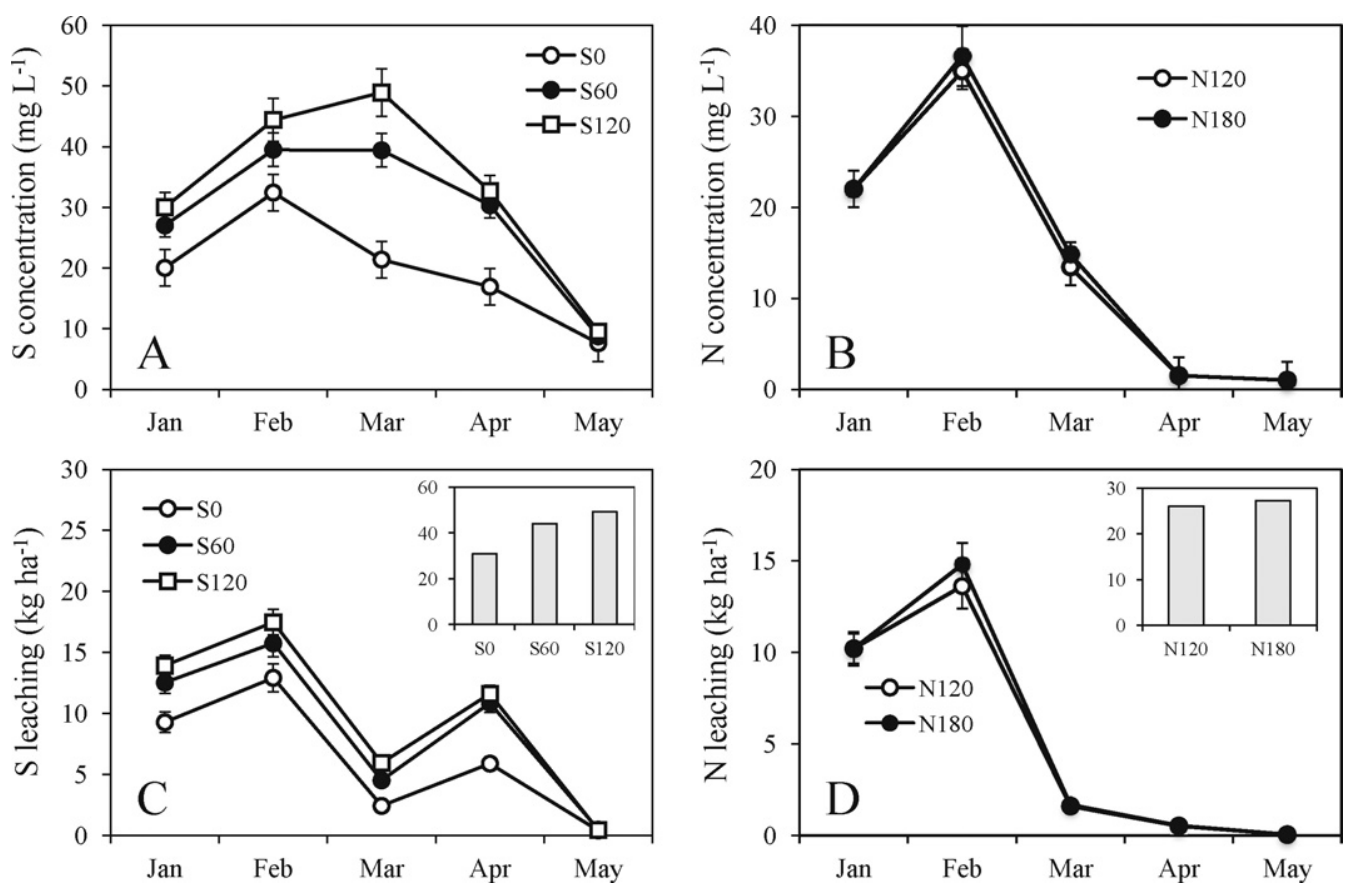

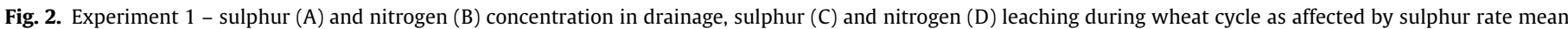
effect. In figures $\mathrm{C}$ and $\mathrm{D}$, values in boxes indicate total $\mathrm{S}$ leaching and total $\mathrm{N}$ leaching, respectively. Vertical bars indicate standard error.

\subsubsection{Sulphur concentration and content}

Sulphur concentration in all plant parts was affected only by soil type, as values were always higher for plants grown in clay loam soil, compared to sandy loam soil. The increase ranged from 30 to $35 \%$ in aerial plant parts and was $42 \%$ in roots (results not shown).

The differences between varieties in $S$ content of all plant parts were similar to those observed in dry weight: Svevo showed higher $\mathrm{S}$ content in grain and lower in leaves, culms and roots (Table 6). The plant uptake of $S$ was $30.8 \mathrm{~kg} \mathrm{ha}^{-1}$ for Svevo and $33.5 \mathrm{~kg} \mathrm{ha}^{-1}$ for Creso, accounted for mainly by vegetative plant part, while grain accounted for only $27 \%$ in Svevo and $22 \%$ in Creso.

Soil type greatly affected $S$ content of plants. Plants grown in clay loam soil had higher $\mathrm{S}$ content in all plant parts except chaff, compared to sandy loam soil. The increase was $90 \%$ for grain and leaves, $100 \%$ for culms and nearly $50 \%$ for roots (Table 6 ).

Sulphur content in all plant parts was affected by S splitting, decreasing in the following order: S60-60, S34-84 and S120-0 (Table 6). The treatment S60-60 increased S uptake of the whole

Table 4

Experiment 1 - sulphur balance (inputs minus outputs) based on average of varieties $\left(\mathrm{kg} \mathrm{Sha}^{-1}\right)$ with SE in brackets.

\begin{tabular}{|c|c|c|c|c|c|c|}
\hline \multicolumn{2}{|l|}{ Treatments } & \multicolumn{2}{|l|}{ Inputs } & \multicolumn{3}{|l|}{ Outputs } \\
\hline Nitrogen rate & Sulphur rate & Wet deposition ${ }^{\mathrm{a}}$ & S fertiliser & Leaching & Plant uptake & Balance \\
\hline \multirow[t]{3}{*}{ N120 } & So & 14.5 & 0.0 & 30.6 & 34.0 & $-50.1(3.4)$ \\
\hline & S60 & 14.5 & 60.0 & 42.8 & 37.6 & $-6.0(1.9)$ \\
\hline & S120 & 14.5 & 120.0 & 49.1 & 39.8 & $45.6(3.1)$ \\
\hline \multirow[t]{3}{*}{ N180 } & So & 14.5 & 0.0 & 31.2 & 42.0 & $-58.7(4.2)$ \\
\hline & S60 & 14.5 & 60.0 & 45.5 & 46.1 & $-17.1(3.0)$ \\
\hline & $\mathrm{S} 120$ & 14.5 & 120.0 & 49.7 & 50.6 & $34.1(3.5)$ \\
\hline
\end{tabular}

a Wet deposition of S was calculated from the volume of the precipitation and the concentration of $\mathrm{S}$ in the precipitation.

Table 5

Experiment 2 - dry weight of grain, leaves, culms, chaff, roots and yield components. Variety, soil type and sulphur splitting mean effects.

\begin{tabular}{|c|c|c|c|c|c|c|c|c|}
\hline Treatments & Grain & Leaves & Culms & Chaff & Roots & Spike number & Kernel number & Mean kernel wt. \\
\hline & & & $\left(\right.$ tha $\left.^{-1}\right)$ & & & $\left(\mathrm{n} \mathrm{m}^{-2}\right)$ & $\left(\right.$ n spike $^{-1}$ ) & $(\mathrm{mg})$ \\
\hline \multicolumn{9}{|l|}{ Variety } \\
\hline Svevo & $5.5 \mathrm{a}$ & $1.0 \mathrm{a}$ & $4.6 \mathrm{a}$ & $1.2 \mathrm{a}$ & $1.5 \mathrm{a}$ & $513.8 \mathrm{a}$ & $23.7 \mathrm{a}$ & $45.1 \mathrm{a}$ \\
\hline Creso & $4.9 \mathrm{~b}$ & $1.2 \mathrm{a}$ & $5.4 \mathrm{~b}$ & $1.2 \mathrm{a}$ & $1.6 \mathrm{a}$ & $523.9 \mathrm{a}$ & $23.1 \mathrm{a}$ & $40.8 \mathrm{~b}$ \\
\hline \multicolumn{9}{|l|}{ Soil type } \\
\hline Clay loam & $6.1 \mathrm{a}$ & $1.3 \mathrm{a}$ & $6.0 \mathrm{a}$ & $1.2 \mathrm{a}$ & $1.6 \mathrm{a}$ & $534.4 \mathrm{a}$ & $24.5 \mathrm{a}$ & $46.9 \mathrm{a}$ \\
\hline Sandy loam & $4.3 \mathrm{~b}$ & $0.9 \mathrm{~b}$ & $4.0 \mathrm{~b}$ & $1.2 \mathrm{a}$ & $1.5 \mathrm{a}$ & $503.3 \mathrm{a}$ & $22.3 \mathrm{~b}$ & $39.0 \mathrm{~b}$ \\
\hline \multicolumn{9}{|l|}{ S splitting } \\
\hline S120-0 & $5.2 \mathrm{a}$ & $1.1 \mathrm{a}$ & $4.9 \mathrm{a}$ & $1.2 \mathrm{a}$ & $1.4 \mathrm{a}$ & $510.1 \mathrm{a}$ & $25.2 \mathrm{a}$ & $39.8 \mathrm{a}$ \\
\hline S60-60 & $5.3 \mathrm{~b}$ & $1.1 \mathrm{a}$ & $5.1 \mathrm{a}$ & $1.2 \mathrm{a}$ & $1.7 \mathrm{~b}$ & $535.6 \mathrm{~b}$ & $24.3 \mathrm{a}$ & $40.6 \mathrm{a}$ \\
\hline S36-84 & $5.1 \mathrm{a}$ & $1.1 \mathrm{a}$ & $4.9 \mathrm{a}$ & $1.2 \mathrm{a}$ & $1.5 \mathrm{ab}$ & $510.8 \mathrm{a}$ & $20.7 \mathrm{~b}$ & $48.3 \mathrm{~b}$ \\
\hline
\end{tabular}

Within treatments variety, soil type and S splitting, numbers followed by the same letter are not significantly different at $P<0.05$. 
Table 6

Experiment 2 - sulphur content of grain, leaves, culms, and roots. Variety, soil type and sulphur splitting mean effects.

\begin{tabular}{|c|c|c|c|c|}
\hline Treatments & Grain & Leaves & Culms & Roots \\
\hline & \multicolumn{4}{|c|}{$\left(\mathrm{kg} \mathrm{ha}^{-1}\right)$} \\
\hline \multicolumn{5}{|l|}{ Variety } \\
\hline Svevo & $8.4 \mathrm{a}$ & $1.7 \mathrm{a}$ & $8.4 \mathrm{a}$ & $10.4 \mathrm{a}$ \\
\hline Creso & $7.4 \mathrm{~b}$ & $1.9 \mathrm{a}$ & $10.3 \mathrm{~b}$ & $12.0 \mathrm{~b}$ \\
\hline \multicolumn{5}{|l|}{ Soil type } \\
\hline Clay loam & $10.3 \mathrm{a}$ & $2.3 \mathrm{a}$ & $12.5 \mathrm{a}$ & $13.4 \mathrm{a}$ \\
\hline Sandy loam & $5.5 \mathrm{~b}$ & $1.2 \mathrm{~b}$ & $6.2 \mathrm{~b}$ & $9.1 \mathrm{~b}$ \\
\hline \multicolumn{5}{|l|}{ S splitting } \\
\hline S120 & $6.9 \mathrm{a}$ & $1.6 \mathrm{a}$ & $8.9 \mathrm{a}$ & $9.6 \mathrm{a}$ \\
\hline S60-60 & $9.0 \mathrm{~b}$ & $1.8 \mathrm{a}$ & $9.9 \mathrm{~b}$ & $12.3 \mathrm{~b}$ \\
\hline S36-84 & $7.8 \mathrm{ab}$ & $1.9 \mathrm{a}$ & $9.2 \mathrm{ab}$ & $11.8 \mathrm{~b}$ \\
\hline
\end{tabular}

Within treatments variety, soil type and sulphur splitting, numbers followed by the same letter are not significantly different at $P<0.05$.

Table 7

Experiment 2 - nitrogen content of grain, leaves, culms and roots. Variety, soil type and sulphur splitting mean effects.

\begin{tabular}{lrrrr}
\hline Treatments & Grain & Leaves & Culms & Roots \\
\hline & \multicolumn{3}{c}{$\left(\mathrm{kg} \mathrm{ha}^{-1}\right)$} \\
\cline { 2 - 5 } & & & \\
Variety & $121.1 \mathrm{a}$ & $10.7 \mathrm{a}$ & $14.7 \mathrm{a}$ & $12.7 \mathrm{a}$ \\
$\quad$ Svevo & $104.7 \mathrm{~b}$ & $12.9 \mathrm{~b}$ & $20.0 \mathrm{~b}$ & $14.5 \mathrm{~b}$ \\
$\quad$ Creso & & & \\
Soil type & $136.1 \mathrm{a}$ & $14.2 \mathrm{a}$ & $20.9 \mathrm{a}$ & $14.5 \mathrm{a}$ \\
$\quad$ Clay loam & $89.7 \mathrm{~b}$ & $9.4 \mathrm{~b}$ & $13.7 \mathrm{~b}$ & $12.7 \mathrm{~b}$ \\
Sandy loam & & & & \\
S splitting & $108.5 \mathrm{a}$ & $11.0 \mathrm{a}$ & $17.1 \mathrm{a}$ & $11.5 \mathrm{a}$ \\
S120-0 & $118.7 \mathrm{~b}$ & $12.1 \mathrm{a}$ & $17.5 \mathrm{a}$ & $15.3 \mathrm{~b}$ \\
S60-60 & $111.5 \mathrm{a}$ & $12.3 \mathrm{a}$ & $17.4 \mathrm{a}$ & $14.0 \mathrm{~b}$ \\
S36-84 & &
\end{tabular}

Within treatments variety, soil type and sulphur splitting, numbers followed by the same letter are not significantly different at $P<0.05$.

plant by $2.4 \mathrm{~kg} \mathrm{ha}^{-1}$ respect to S36-84 and by $6.2 \mathrm{~kg} \mathrm{ha}^{-1}$ respect to S120-0.

\subsubsection{Nitrogen concentration and content}

Nitrogen concentration in all plant parts was not modified by treatments. Grain N content was 16\% higher in Svevo than Creso, while leaves, culms and roots were 20,36 and $15 \%$ lower, respectively. At a whole, $\mathrm{N}$ plant uptake was only $4 \%$ lower in Creso.

Plants grown in clay loam soil had $\mathrm{N}$ content in grain, leaves and culms by $52 \%$ higher and $N$ content in roots by $14 \%$ higher compared to plants grown in sandy soil (Table 7).

The splitting of $\mathrm{S}$ application preplanting and after seeding (S60-60) increased $\mathrm{N}$ content of grain, leaves, culms and roots compared to the other two applications, although only the differences in grain $\mathrm{N}$ content were statistically significant. All summarised, $\mathrm{N}$ uptake by plants ranged from $157 \mathrm{~kg} \mathrm{ha}^{-1}$ of S120-0 to $173 \mathrm{~kg} \mathrm{ha}^{-1}$ of S60-60 (results not shown).

\subsubsection{Sulphur leaching}

The amount of drainage water and sulphur leaching increased during winter as the rainfall increased. Rainfall during 2004-2005 wheat growing season was lower than normal, with a total amount only $55 \%$ of the 100 -year mean of the site. Soil type and S splitting affected sulphur concentration in drainage water and S leaching. The concentration of $S$ in drainage from clay loam soil was always higher than the one from sandy loam soil at all S splittings, but differences decreased throughout the wheat cycle (Fig. 3). The decrease of $\mathrm{S}$ fertiliser applied preplanting reduced by $15-37 \% \mathrm{~S}$ concentration in the drainages collected in January, February and March (Fig. 3). Consequently, S losses from clay loam soil were higher than the ones from sandy loam soil and decreased when the application of $\mathrm{S}$ fertiliser before seeding was reduced.

Over the whole wheat cycle, $S$ leaching was affected by the interaction between soil type and $S$ splitting. The quantities of S lost from clay loam soil were consistently higher than the ones from sandy loam soil, but $\mathrm{S}$ splitting reduced losses less in sandy loam soil than in clay loam soil (Fig. 3).

\subsubsection{Nitrogen leaching}

Drainage, $\mathrm{N}$ concentration in drainage and leached $\mathrm{N}$ were affected only by soil type. Drainage from sandy loam soil in January and March was 56 and $52 \mathrm{~m}^{3} \mathrm{ha}^{-1}$ greater, respectively, than the one from clay loam soil, while drainage in February and April were similar in the two soil types (Fig. 4).

The concentrations of $\mathrm{N}$ in drainage from both soil types varied during wheat cycle and were higher in February. Values from clay loam soil were consistently higher than sandy loam soil in January and February, while in the later drainages values were low and similar between soils (Fig. 4). Similarly, the quantity of N leaching from clay loam soil was higher than sandy loam soil in January and February, while in March and April $\mathrm{N}$ leaching was very low for both soils (Fig. 4). Over the wheat cycle, $32 \mathrm{~kg} \mathrm{~N} \mathrm{ha}^{-1}$ were lost by leaching from clay loam soil and $21 \mathrm{~kg} \mathrm{~N} \mathrm{ha}^{-1}$ were lost from sandy loam soil.

\subsubsection{Sulphur balance}

Averaged over varieties, $S$ leaching accounted for $40-53 \%$ of the total output from soil (leaching plus plant uptake) (Table 8). The input and output balance was positive for all treatments, showing a surplus of $S$ in soil ranging from 51 to $85 \mathrm{~kg} \mathrm{ha}^{-1}$ (Table 8). The surplus was not substantially modified by $S$ splitting and was more strongly affected by soil type: averaged over varieties and S splitting rates, the surplus of $\mathrm{S}$ from sandy loam soil was by $50 \%$ higher.
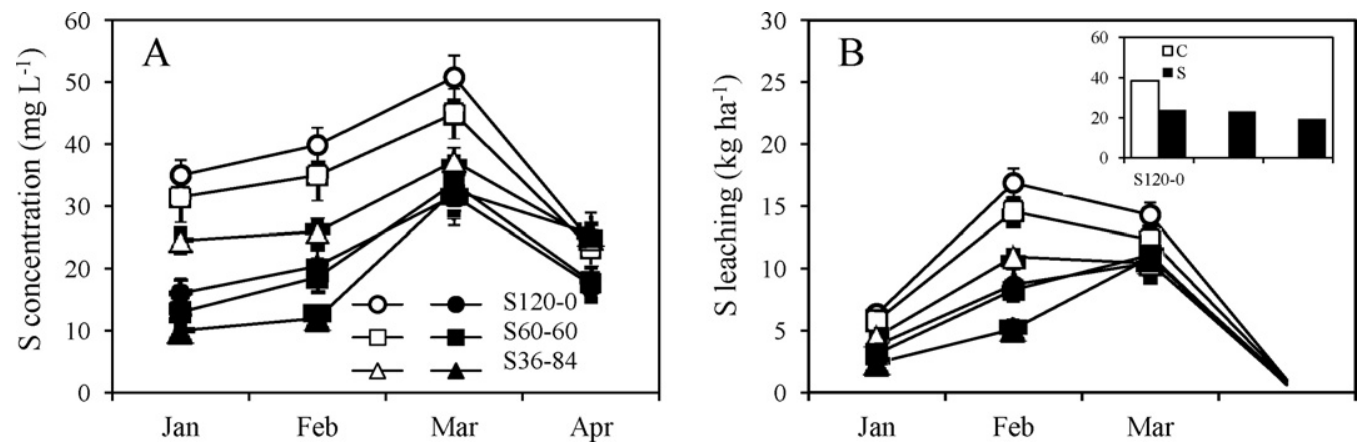

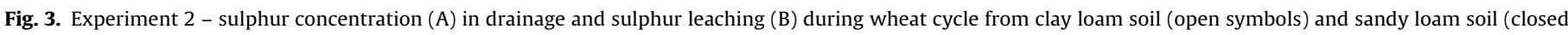
symbols) as affected by sulphur splitting. In figure B, values in box indicate total S leaching. Vertical bars indicate standard error. 
Table 8

Experiment 2 - sulphur balance (inputs minus outputs) based on average of varieties $\left(\mathrm{kg} \mathrm{Sha}^{-1}\right)$ with SE in brackets.

\begin{tabular}{|c|c|c|c|c|c|c|}
\hline \multicolumn{2}{|l|}{ Treatments } & \multicolumn{2}{|l|}{ Inputs } & \multicolumn{2}{|l|}{ Outputs } & \multirow[t]{2}{*}{ Balance } \\
\hline Soil type & S splitting & Wet deposition ${ }^{\mathrm{a}}$ & S fertiliser & Leaching & Plant uptake & \\
\hline \multirow{3}{*}{ Clay-loam } & S120-0 & 9.4 & 120.0 & 38.5 & 37.0 & $53.9(4.2)$ \\
\hline & S60-60 & 9.4 & 120.0 & 33.7 & 44.6 & $51.1(4.9)$ \\
\hline & S36-84 & 9.4 & 120.0 & 26.8 & 40.3 & $62.3(5.7)$ \\
\hline \multirow[t]{3}{*}{ Sandy-loam } & S120-0 & 9.4 & 120.0 & 23.7 & 20.6 & $85.1(7.4)$ \\
\hline & S60-60 & 9.4 & 120.0 & 23.1 & 25.5 & $80.8(6.3)$ \\
\hline & S36-84 & 9.4 & 120.0 & 19.3 & 25.0 & $85.1(6.6)$ \\
\hline
\end{tabular}

a Wet deposition of S was calculated from the volume of the precipitation and the concentration of S in the precipitation.
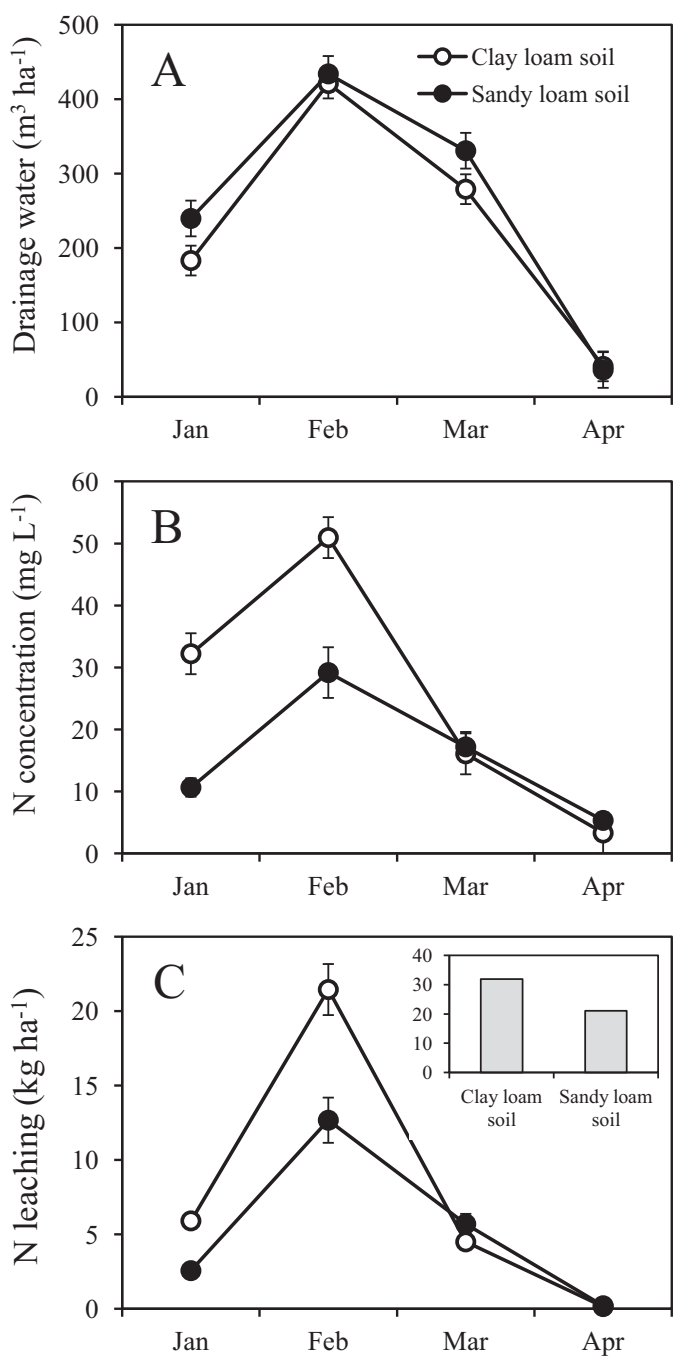

Fig. 4. Experiment 2 - drainage water (A), nitrogen concentration in drainage (B) and nitrogen leaching $(C)$ during wheat cycle as affected by soil type mean effect. In figure $\mathrm{C}$, values in box indicate total $\mathrm{N}$ leaching. Vertical bars indicate standard error.

\section{Discussion}

\subsection{Responses to $\mathrm{N}$ fertiliser}

Nitrogen fertiliser increased grain yield and dry weight of all plant parts except chaff of both varieties. This response was similar to that reported by Ercoli et al. (2011) in the field under the same environmental conditions and applying the same $\mathrm{N}$ rates, though plants grown in lysimeters gave higher yield, probably because they were exposed to more favourable conditions. Results of this research indicate that crop fertilised with $120 \mathrm{~kg} \mathrm{~N} \mathrm{ha}^{-1}$ had less than optimal soil $\mathrm{N}$ availability for growth. The rise of $\mathrm{N}$ rate did not affect $\mathrm{N}$ concentration of all plant parts, but their $\mathrm{N}$ content was increased owing to the effect on dry weight. Nitrogen fertiliser did not affect $S$ concentration in all plant parts and consequently variations in their $\mathrm{S}$ contents were due to variations in dry matter prompted by $\mathrm{N}$ rate.

Differences between varieties in the capacity to accumulate $\mathrm{N}$ in grain were not evident in this trial: Svevo had higher grain yield and $\mathrm{N}$ and $\mathrm{S}$ uptake but the response to fertiliser treatments was similar for both varieties.

As expected in Mediterranean environments, where rainfall is concentrated in autumn and winter when plant $\mathrm{N}$ uptake is low, in our experiment leaching losses of $\mathrm{N}$ occurred mainly in January and February, which accounted for over $90 \%$ of the total leaching loss. This was to be expected since the differentiation between the two $\mathrm{N}$ treatments occurred late in March, when rainfall and the consequent drainage volume were low. It is worth noting that in April drainage volume was high, but $\mathrm{N}$ concentration was very low, probably as a consequence of high plant uptake. Thus, the timing of $\mathrm{N}$ distribution is crucial to minimise $\mathrm{N}$ leaching losses. The benefits obtained with the higher $\mathrm{N}$ rate relied on the fulfillment of crop requirements coupled with minimised $\mathrm{N}$ losses.

\subsection{Responses to $S$ fertiliser rate}

Sulphur application increased dry weight and S uptake of all plant parts except chaff, but only grain and roots had higher $S$ concentration at higher $\mathrm{S}$ rate. Grain yield increase was mainly due to an increase of the number of kernels per spike, which was interpreted as a stimulation of the initiation of spikelets and/or florets, or to a reduction of floret mortality (Archer, 1974; Monaghan et al., 1997; Ercoli et al., 2011).

Sulphur fertiliser also increased $\mathrm{N}$ content of grain, culms and roots. At low $\mathrm{N}$ availability, sulphur fertilisation stimulated $\mathrm{N}$ accumulation in roots. The response of all plant parts, except roots, to $\mathrm{N}$ and $S$ fertiliser agree with our previous research, where we could not demonstrate any synergism between $\mathrm{N}$ and $\mathrm{S}$ rate, which does not support the hypothesis of Zhao et al. (1999) and Flæte et al. (2005), asserting that crop response to S fertilisation depends on the amount of $\mathrm{N}$ fertiliser, and that $\mathrm{S}$ deficiency may be induced by a high amount of $\mathrm{N}$ supply. Probably, in our experiment plants fertilised with $180 \mathrm{~kg} \mathrm{~N} \mathrm{ha}^{-1}$ were not driven to $\mathrm{S}$ deficiency.

The positive effect of S application on dry matter and S uptake was detected already at S60 and no further significant effect was evidenced with the higher rate. Thus, we can assume that S60 is not limiting in our environment. Our previous research, carried out in the same environment in the field, found that $\mathrm{S}$ concentration in grain increased and grain quality was improved when $S$ application went beyond the maximum grain yield, which probably indicates a luxury consumption (Ercoli et al., 2011).

Averaged over the seasons 2003-2004 and 2004-2005, S leaching during the whole wheat cycle was $35 \mathrm{kgSha}^{-1}$, which was equivalent to $48 \%$ of the total output of the crops. Sulphur 
leaching in the period March-April accounted for $24-45 \%$ of the total amount of S leached during wheat cycle. Thus, in our environment, the risk of high $\mathrm{S}$ losses by leaching is high especially in spring, due to the low S uptake by the plants and the high release of $\mathrm{S}$ by the decomposing organic matter in soil. Sulphur fertiliser rate increased $S$ concentration in drainage water and consequently $\mathrm{S}$ leached during wheat cycle. Compared to unfertilised control, $\mathrm{S}$ leached was by $13 \mathrm{~kg} \mathrm{ha}^{-1}$ higher at S60 and by $19 \mathrm{~kg} \mathrm{ha}^{-1}$ higher at $\mathrm{S} 120$.

\subsection{Responses to S fertiliser splitting}

In field conditions, sulphur nutrition of wheat may be restricted as the $S$ availability in soil is not necessarily synchronised with plant needs and the redistribution of S from vegetative tissues to grain is considerably less than for N (Monaghan et al., 1999). Hocking (1994) found that only about 33\% of the $S$ in stem and leaves was redistributed to the grain, compared to approximately $75 \%$ for $\mathrm{N}$. This implies that the $\mathrm{S}$ availability needs to be maintained at sufficient levels throughout the whole period of growth to achieve adequate accumulation of S in the grain (Flæte et al., 2005).

In our research, $S$ availability during crop cycle affected the initiation and development of plant organs and hence grain and yield components. The splitting of sulphur fertiliser during crop cycle modified grain yield. The highest grain yield was obtained with the application of $60 \mathrm{~kg} \mathrm{Sha}^{-1}$ before seeding and $60 \mathrm{~kg} \mathrm{Sha}^{-1}$ at stem elongation. The application of $\mathrm{S}$ entirely before seeding or splitted $36 \mathrm{~kg} \mathrm{Sha}^{-1}$ before seeding and $84 \mathrm{~kg} \mathrm{Sha}^{-1}$ at stem elongation gave similar yields, but values were obtained with different contributions of yield components: higher kernel number per spike for the former and higher mean kernel weight for the latter. Thus, a higher S availability at seeding promoted the development of spikebearing culms and the spike size, while the higher availability at the beginning of stem elongation favoured the accumulation of assimilates into grain. Sulphur splitting also increased $\mathrm{N}$ and $\mathrm{S}$ uptake of plants: the highest $\mathrm{N}$ and $\mathrm{S}$ uptake were recorded with application of S60-60. The effect of the splitting of S fertiliser was similar for both varieties, as expected, and also for soil types, as no interaction was detected for any of the measured characters. Thus we can conclude that the timing of S application did not modify the mineralisation and immobilisation pattern of sulphur in soil, and the variations during wheat cycle of $\mathrm{S}$ application rate were probably not high enough to give rise to differences in S availability by modifications of the mobilisation/immobilisation balance.

Sulphur splitting modified also the quantities of S lost by leaching: $S$ application later during wheat cycle reduced $S$ losses by leaching and the effect was higher in clay loam soil, which confirms its higher retention capacity of S. However, sulphate leaching that occurred when $\mathrm{S}$ was applied before seeding is not expected to have a detrimental environmental impact, since the peak $\mathrm{S}$ concentration ( $50.8 \mathrm{mg} \mathrm{L}^{-1}$ in March) was well below the EC limit of $83 \mathrm{mg} \mathrm{S} \mathrm{L}^{-1}$ in drinking water (directive 98/83/EC). Thus the benefits from $S$ splitting rely only on the increase of sulphur fertiliser use efficiency.

Plant dry weight and S uptake were also higher in clay loam soil than in sandy soil, as soils with a higher clay content and thus higher storage capacity for water have a higher production potential and consequently $\mathrm{S}$ removal of crops grown increases with rising clay content (Pedersen et al., 1998). Light textured soils are generally believed to be most at risk of $S$ leaching because of the ease with which the leachate moves through the soil and also because such soils have low absorption capacities (Walker and Gregg, 1975; McGrath and Zhao, 1995). Conversely, in our research higher $\mathrm{S}$ losses occurred from clay loam soil compared to sandy loam soil. Work of Eriksen et al. (1995) indicated great differences in net mineralisation of S among different soils and suggested that mineralised S was not significantly correlated with total organic S contents of the soil but with microbial activity.

\subsection{Sulphur balance}

Several studies have shown the importance of availability of soil $S$ during crop growth and the need to apply additional $S$ fertilisers to avoid S deficiency symptoms (Curtin and Syers, 1990; Guzys and Aksomaitiene, 2005). In durum wheat $S$ nutrition is also crucial to improve grain quality (Lerner et al., 2006; Ercoli et al., 2011). A mass balance approach for determining the $S$ fertiliser rate should be applied in order to reduce environmental losses of S and depletion of $S$ in soil (Eriksen et al., 1995).

In our research, an equilibrium between $S$ input and output was not reached, as the overall $\mathrm{S}$ balance greatly differed in the two experiments, being highly positive or seriously negative. The $S$ balance was positive in both experiments only when the higher $S$ rate was applied, as more $S$ was imported than removed. Thus, no substantial S deficit may be expected in short term, provided that high $\mathrm{S}$ fertiliser rate is applied and the availability of $\mathrm{S}$ is synchronised with plant needs.

Previous studies have reported no effect of S fertilisation on mineralisation-immobilisation processes (Wu et al., 1995; Knights et al., 2001) or reduced immobilisation and gross mineralisation (Nziguheba et al., 2005). Our study showed that in the unfertilised plots net mineralisation of soil organic $S$ must have contributed substantially to both leaching and plant uptake of $S$, while in the fertilised plots both deficit and surplus were evidenced, suggesting either a depletion of soil organic $S$ reserves or an immobilisation of fertiliser $\mathrm{S}$. However to show more explicitly how the $\mathrm{S}$ balance and availability in soil are affected by $S$ fertilisation in our environment, long-term data obtained with radioactive tracers should be considered.

\section{Conclusions}

These results indicate that in Mediterranean regions with high winter rainfall significant leaching losses of S are likely to occur in soils with high organic S content. Because $S$ is readily leached, $S$ applications should be timed to coincide with the phase of high demand by crops, which usually means in late spring rather than in autumn, and management options generally employed for minimising nitrate leaching should also be applied to $S$ fertilisers. Moreover, it seems clear that if crop yield and quality are to be maintained at present levels, plant $S$ uptake and S leaching must, at least in part, be replaced by $S$ fertilisation because $S$ mineralisation cannot fulfill the $S$ demand of the wheat crop.

\section{References}

Archer, M.J., 1974. A sand culture experiment to compare the effects of sulphur on five wheat cultivars (T. aestivum L.). Aust. J. Agric. Res. 25, 369-380.

Arowolo, T.A., Cresser, M.S., Edwards, A.C., 1994. Impact of land use and soil types on the contribution of sulphate to total sulphur in drainage waters from upland soils. Sci. Total Environ. 158, 139-146.

Barber, S.A., 1995. Soil Nutrient Bioavailability. John Wiley Sons, New York.

Bohn, H.L., Barrow, N.J., Rajan, S.S.S., Parfitt, R.L., 1986. Reactions of inorganic sulfur in soils. In: Tabatabai, M.A. (Ed.), Sulfur in Agriculture. Agron. Monogr., vol. 27. ASA, CSSA, and ISSSA, Madison, WI, pp. 233-249.

Chao, T.T., Harward, M.E., Fang, S.C., 1962. Adsorption and desorption phenomena of sulphate ions in soils. Soil Sci. Soc. Am. Proc. 26, 234-237.

Curtin, D., Syers, J.K., 1990. Extractability and adsorption of sulphate in soils. J. Soil Sci. 41, 295-304.

de Ruiter, J.M., Martin, R.J., 2001. Management of nitrogen and sulphur fertiliser for improved bread wheat (Triticum aestivum) quality. N.Z. J. Crop Hort. 29, 287-299.

Ercoli, L., Lulli, L., Arduini, I., Mariotti, M., Masoni, A., 2011. Durum wheat grain yield and quality as affected by $S$ rate under Mediterranean conditions. Eur. J. Agron. $35,63-70$. 
Eriksen, J., Mortensen, J.V., Dissing Nielsen, J., Nielsen, N.E., 1995. Sulphur mineralisation in five Danish soils as measured by plant uptake in a pot experiment. Agric. Ecosyst. Environ. 56, 43-51.

Eriksen, J., Murphy, M.D., Schnug, E., 1998. The soil sulphur cycle. In: Schnug, E. (Ed.), Sulphur in Agroecosystems. Kluwer Academic Press, The Netherlands, pp. 39-73.

Eriksen, J., Askegaard, M., 2000. Sulphate leaching in an organic crop rotation on sandy soil in Denmark. Agric. Ecosyst. Environ. 78, 107-114.

Eriksen, J., Olesen, J.E., Askegaard, M., 2002. Sulphate leaching and sulphur balances of an organic cereal crop rotation on three Danish soils. Eur. J. Agron. 17, 1-9.

Eriksen, J., 2009. Sulfur cycling in temperate agricultural systems. Adv. Agron. 102, 55-89.

Flæte, N.E.S., Hollung, K., Ruud, L., Sogn, T., Faergestad, E.M., Skarpeid, H.J., Magnus, E.M., Uhlen, A.K., 2005. Combined nitrogen and sulphur fertilisation and its effect on wheat quality and protein composition measured by SE-FPLC and proteomics. J. Cereal Sci. 41, 357-369.

Ghani, A., McLaren, R.G., Swift, R.S., 1993. Mobilization of recently-formed soil organic sulphur. Soil Biol. Biochem. 25, 1739-1744.

Guzys, S., Aksomaitiene, R., 2005. Migration of sulphur in limed soils differing in agricultural management. Nutr. Cycl. Agroecosyst. 71, 191-201.

Harward, M.E., Reisenauer, H.M., 1966. Reactions and movement of inorganic soil sulfur. Soil Sci. 101, 326-335.

Hocking, P.J., 1994. Dry-matter production, mineral nutrient concentration, and nutrient distribution and re-distribution in irrigated spring wheat. J. Plant Nutr. 17, 1289-1308.

Knights, J.S., Zhao, F.J., McGrath, S.P., Magan, N., 2001. Long-term effects of land use and fertilizer treatments on sulphur transformations in soils from the Broadbalk experiment. Soil Biol. Biochem. 33, 1797-1804.

Korentajer, L., Byrnes, B.H., Hellmus, D.T., 1984. Leaching losses and plant recovery from various sulfur fertilizers. Soil Sci. Soc. Am. J. 48, 671-676.

Lerner, S.E., Seghezzo, M.L., Molfese, E.R., Ponzio, N.R., Cogliatti, M., Rogers, W.J., 2006. N- and S-fertiliser effects on grain composition, industrial quality and end-use in durum wheat. J. Cereal Sci. 44, 2-11.

Maynard, D.G., Stewart, J.W.B., Bettany, J.R., 1983. Sulfur and nitrogen mineralization in soils compared using two incubation techniques. Soil Biol. Biochem. 17, 127-134.

McGrath, S.P., Zhao, F.J., 1995. A risk assessment of sulfur deficiency in cereals using soil and atmospheric deposition data. Soil Use Manage. 11, 110-114.

Monaghan, J.M., Evans, E.J., Shewry, P.R., 1997. The effect of amount and timing of $S$ on grain yield and quality of winter wheat. In: Gooding, M.J., Shewry, P.R.
(Eds.), Optimising Cereal Inputs: Its Scientific Basis. The Association of Applied Biologists, Wellesbourne, UK, pp. 231-236.

Monaghan, J.M., Scrimgeour, C.M., Stein, W.M., Zhao, F.J., Evans, E.J., 1999. Sulphur accumulation and redistribution in wheat (Triticum aestivum): a study using stable sulphur isotope ratios as a tracer system. Plant Cell Environ. 22, 831-839.

Moonen, C., Masoni, A., Ercoli, L., Mariotti, M., Bonari, E., 2001. Longterm changes in rainfall and temperature in Pisa, Italy. Agric. Med. 130, 11-22.

Nziguheba, G., Smolders, E., Merckx, R., 2005. Sulphur immobilization and availability in soils assessed using isotope dilution. Soil Biol. Biochem. 37 635-644.

Pedersen, C.A., Knudsen, L., Schnug, E., 1998. Sulphur fertilization. In: Schnug, E. (Ed.), Sulphur in Agroecosystems. Kluwer Academic Press, The Netherlands, pp. $115-134$.

Riley, N.G., Zhao, F.J., McGrath, S.P., 2002. Leaching losses of sulphur from different forms of sulphur fertilizers: a field lysimeter study. Soil Use Manage. 18 , $120-126$.

Scherer, H.W., 2001. Sulphur in crop production - invited paper. Eur. J. Agron. 14 81-111.

Schnug, E., 1991. Sulphur nutritional status of European crops and consequences for agriculture. Sulphur Agric. 15, 7-12.

Schumacher, B.A., Neary, A.J., Palmer, C.J., Maynard, D.G., Pastorek, L., Morrison, I.K., Marsh, M., 1995. Laboratory methods for soil and foliar analysis in long-tem environmental monitoring programs. EPA/600/R-95/077, 178 pp.

Steel, R.G.D., Torrie, J.H., Dickey, D.A., 1997. Principles and Procedures of Statistics: A Biometrical Approach. McGraw-Hill, New York.

Walker, T.V., Gregg, P.E.H., 1975. The occurrence of sulphur deficiency in New Zealand. In: McLachlan, K.D. (Ed.), Sulphur in Australisian Agriculture. Sydney University Press, pp. 145-153.

Wu, J., O’Donnell, A.G., Syers, J.K., 1995. Influence of glucose, nitrogen and plant residues on the immobilization of sulphate-S in soil. Soil Biol. Biochem. 27 1363-1370.

Zadoks, J.C., Chang, T.T., Konzak, C.F., 1974. A decimal code for the growth stages of cereals. Weed Res. 14, 415-421.

Zhao, F., McGrath, S.P., 1994. Soil extractable sulphate and organic sulphur and their availability to plant. Plant Soil 164, 243-250.

Zhao, F.J., Salmon, S.E., Withers, P.T.A., Monaghan, J.M., Evans, E.J., Shewry, P.R. McGrath, S.P., 1999. Variation in the breadmaking quality and rheological properties of wheat in relation to sulphur nutrition under field conditions. J. Cereal Sci. 30, 19-31. 